\title{
St. Jude Stage III Childhood Non-Hodgkin Lymphoma AJCC v8
}

National Cancer Institute

\section{Source}

National Cancer Institute. St. Jude Stage III Childhood Non-Hodgkin Lymphoma A/CC v8. NCI Thesaurus. Code C141220.

Stage III: Two single tumors (extranodal) on opposite sides of the diaphragm. Two or more nodal areas above and below the diaphragm. All the primary intrathoracic tumors (mediastinal, pleural, and thymic). All extensive primary intra-abdominal disease. All paraspinal or epidural tumors, regardless of other tumor site(s). (from AJCC 8th Ed.) 